\title{
Pembuatan Alat Pengadukan Pupuk Kompos Berbasiskan Mikrokontroler
}

\author{
Fabtication Of Compos Mixing Machine Based On Microcontroller
}

\author{
Roza Susanti \\ Jurusan Teknik Elektro, Politeknik Negeri Padang \\ Telp.0751-72590 Fax. 0751-72576 Email: susantiroza@yahoo.com
}

\begin{abstract}
In fabrication of compos mixing machine based on microcontroller, an AC motor 1 phase used to rotate the container and it will help the farmer work in stirring and mixing compos material. In order to display the process, a LCD is use in this fabrication.The design of this machine is divided into two categories, hardware design and software design. The hardware consist of an AVRATmega 8535 microcontroller minimum system, a LCD, Keypad, an AC Motor 1 phase, a Capacitor, and a relay. In the order hand for software design, a Code vision-AVR program language as the program application. The data analysis techniques are conducted by testing the machine performs. Not only by measuring operating voltages, but also testing the microcontroller with a program application.This machine is based on microcontroller AVRATmega8535 and using C language in programming. In order to display the mixing output, time setting is displayed on LCD. The optimum result started from the first 10 seconds ON condition and the second of 10 seconds ON condition should have a 30 seconds time off.
\end{abstract}

Keyword: microcontroller, keypad, LCD, AC motor 1 phase, and relay

\section{PENDAHULUAN}

Pupuk adalah material yang ditambahkan pada media tanam atau tanaman untuk mencukupi kebutuhan hara yang diperlukan tanaman sehingga mampu berproduksi dengan baik. Material pupuk dapat berupa bahan organik ataupun nonorganik (mineral). Pupuk dapat dikelompokkan menjadi dua bagian yaitu pupuk alami dan pupuk buatan. Pupuk alami mencakup semua pupuk yang dibuat dari sisa-sisa metabolisme atau organ hewan dan tumbuhan, sedangkan pupuk buatan dibuat melalui proses pengolahan oleh manusia dari bahan-bahan mineral.

Salah satu contoh dari pupuk alami adalah pupuk kompos. Kompos memperbaiki sifat fisik dan kimia tanah, sehingga akan mengembalikan kesuburan tanah. Tanah keras akan menjadi lebih gembur, tanah yang memiliki tingkat keasaman tinggi akan menjadi lebih netral.

Tanaman yang diberi kompos tumbuh lebih subur dan kualitas panennya lebih baik daripada tanaman tanpa kompos.
Bahan pengolahan pupuk kompos ini terdiri dari tanah, sekam padi, pupuk kandang dan dicampur dengan cairan bakteri. Proses pengolahan pupuk kompos ini masih dilakukan secara manual, yaitu dengan menggunakan tangan dan sekop. Oleh karena itu dibuatlah alat pengaduk yang dapat mempermudah dan memperingan kerja petani.

Tujuan pembuatan penelitian ini adalah Membuat alat pengadukan pupuk kompos berbasiskan mikrokontroller.

Rencana pembuatan penelitian akan dilakukan pengembangan selain pengadukan dan dapat juga menghitung nilai kelembaban dari hasil pengadukan pupuk kompos yang ditampilkan pada LCD yang sangat diperlukan untuk tumbuhan cabe. Setelah dilakukan penelitian ini harapannya dapat digunakan pada penaman cabe.

Kompos adalah hasil penguraian parsial/tidak lengkap dari campuran bahanbahan organik yang dapat dipercepat secara artifisial oleh populasi berbagai macam mikroba dalam kondisi lingkungan yang hangat, lembap, dan aerobik atau anaerobik 
(Modifikasi dari J.H. Crawford, 2003). Sedangkan pengomposan adalah proses dimana bahan organik mengalami penguraian secara biologis, khususnya oleh mikroba-mikroba yang memanfaatkan bahan organik sebagai sumber energi. Membuat kompos adalah mengatur dan mengontrol proses alami tersebut agar kompos dapat terbentuk lebih cepat. Proses ini meliputi membuat campuran bahan yang seimbang, pemberian air yang cukup, pengaturan aerasi, dan penambahan aktivator pengomposan.

Kompos memperbaiki struktur tanah dengan meningkatkan kandungan bahan organik tanah dan akan meningkatkan kemampuan tanah untuk mempertahankan kandungan air tanah. Aktivitas mikroba tanah yang bermanfaat bagi tanaman akan meningkat dengan penambahan kompos. Aktivitas mikroba ini membantu tanaman untuk menyerap unsur hara dari tanah. Aktivitas mikroba tanah juga d iketahui dapat membantu tanaman menghadapi serangan penyakit.

Tanaman yang dipupuk dengan kompos juga cenderung lebih baik kualitasnya daripada tanaman yang dipupuk dengan pupuk kimia, seperti menjadikan hasil panen lebih tahan disimpan, lebih berat, lebih segar, dan lebih enak.

Mikrokontroler adalah pusat kerja dari suatu sistem elektronika seperti halnya mikroprosesor sebagai otak komputer. Adapun nilai plus bagi mikrokontroler adalah terdapatnya memori dan port input/output dalam suatu kemasan IC yang kompak. Kemampuannya yang programmable, fitur yang lengkap seperti ADC internal, EEPROM internal, port I/O, komunikasi serial, juga harga yang terjangkau memungkinkan mikrokontroler digunakan pada berbagai sistem elektronik, seperti pada robot, automasi industri, sistem alarm, peralatan telekomunikasi, hingga sistem keamanan. Mikrokontroler AVR memiliki arsitektur RISC 8 bit, dimana semua instruksi dikemas dalam kode 16 bit dan sebagian besar instruksi dalam 1 (satu) siklus clock, berbeda dengan instruksi
MCS51 yang membutuhkan 12 siklus clock. Hal ini terjadi karena kedua jenis mikrokontroler tersebut memiliki arsitektur yang berbeda. AVR berteknologi RISC (Reduced Instruction Set Computing), sedangkan seri MCS51 berteknologi CISC (Complex Instruction Set Computing). Secara umum, AVR dapat dikelompokkan menjadi 4 klas, yaitu keluarga ATtiny, keluarga AT90Sxx, keluarga ATMega, dan AT86RFxx. Pada dasarnya, yang membeda-bedakan masing-masing klas adalah memori, peripheral, dan fungsinya. Dari segi arsitektur dan instruksi yang digunakan, mereka bisa dikatakan hampir sama. Piranti dapat diprogram secara insystem programming (ISP) dan dapat diprogram berulang-ulang selama 10.000 kali baca/tulis didalam system.

Mikrokonktroler digunakan dalam alat yang dikendalikan secara automatis, seperti sistem kontrol mesin, remote controls, mesin kantor, peralatan rumah tangga, alat berat, dan mainan. Dengan mengurangi ukuran, biaya, dan konsumsi tenaga dibandingkan dengan mendesain menggunakan mikroprosesor memori, dan alat input output yang terpisah, kehadiran mikrokontroler membuat kontrol elektrik untuk berbagai proses menjadi lebih ekonomis. Kelebihan penggunaan mikrokontroler ini maka

1. Sistem elektronik akan menjadi lebih ringkas.

2. Rancang bangun sistem elektronik akan lebih cepat karena sebagian besar dari sistem adalah perangkat lunak yang mudah dimodifikasi.

3. Pencarian gangguan lebih mudah ditelusuri karena sistemnya yang kompak

Agar sebuah mikrokontroler dapat berfungsi, maka diperlukan komponen eksternal yang kemudian disebut dengan sistem minimum.Untuk merancang sebuah sistem berbasis mikrokontroler, kita memerlukan perangkat keras dan perangkat lunak 


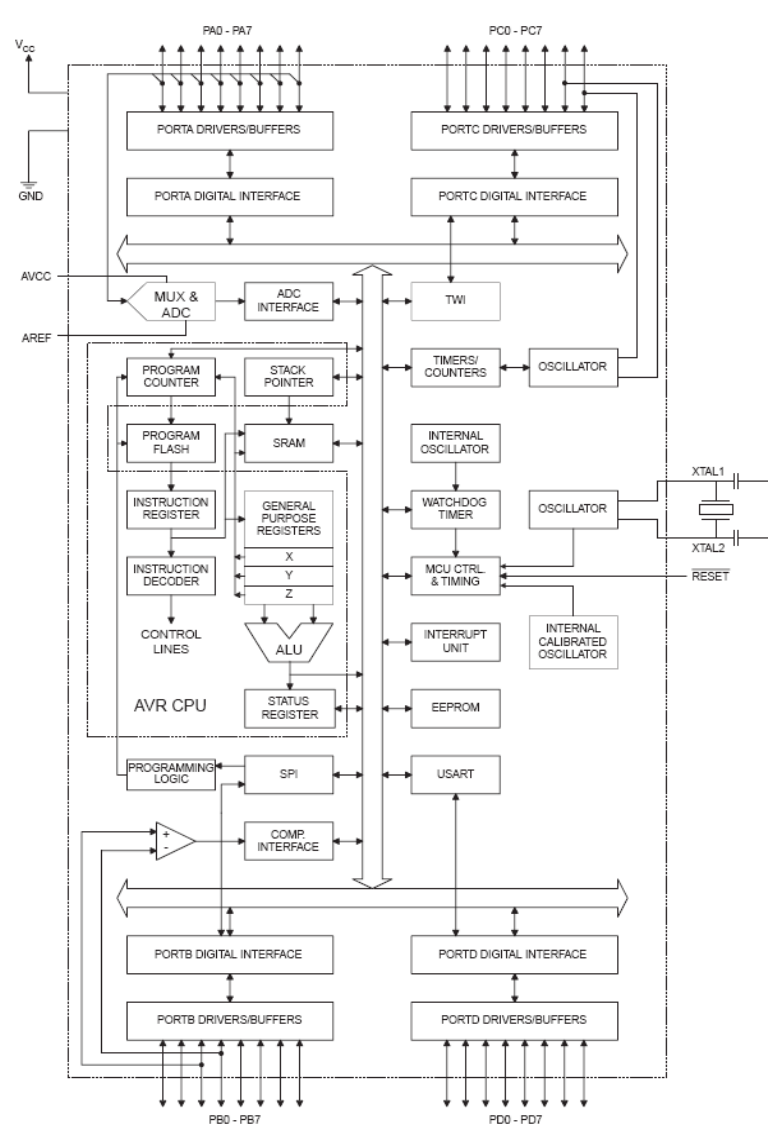

Gambar 1. Blok Diagram Fungsional ATMega8535

Atmel AVR adalah salah satu jenis mikrokontroler yang sering digunakan dalam bidang elektronik dan instrumentasi. Mikrokonktroler AVR (Alv and Vegard's Risc Processor) merupakan mikrokonktroler RISC 8 bit. Karena RISC (Reduce Instruction Set Computing) inilah sebagian besar kode instruksinya dikemas dalam satu siklus clock.AVR adalah jenis mikrokontroler yang paling sering dipakai dalam bidang elektronika dan instrumentasi. Secara umum AVR dapat dikelompokkan dalam 4 kelas. Pada dasarnya yang membedakan masing-masing kelas adalah memori, peripheral dan fungsinya.Keempat kelas tersebut adalah keluarga ATTiny, keluarga AT90Sxx, keluarga ATMega dan AT86RFxx. Dari gambar 1 dapat dilihat bahwa ATMega8535 memiliki bagianbagian sebagai berikut:

1. Saluran I/O sebanyak 32 buah, yaitu Port A, Port B, Port C, dan Port D 2. ADC 10 bit sebanyak 8 saluran.

3. Tiga buah Timer/Counter dengan kemampuan pembandingan.

4. CPU yang terdiri atas 32 buah register.

5. Watchdog Timer dengan osilator internal.

6. SRAM sebesar 512 byte.

7. Memori Flash sebesar $8 \mathrm{~kb}$ dengan kemampuan Read While Write.

8. Unit interupsi internal dan eksternal.

9. Port antarmuka SPI.

10. EEPROM sebesar 512 byte yang dapat deprogram saat operasi.

11. Antarmuka komparator analog.

12. Port USART untuk komunikasi serial.

Code Vision AVR adalah sebuah cross-compiler $\quad C, \quad$ Integrated Development Environtment(IDE) dan Automatic Program Generator yang didesain untuk milrokontroler buatan Atmel seri AVR. IDE mempunyai fasilitas internal berupa software AVR Chip InSystem Programmer yang dapat digunakan untuk melakukan transfer program kedalam chip mikrokontroler setelah sukses melakukan proses kompilasi/assembly secara otomatis. Software In-System Programmer didesain untuk dapat bekerja dengan Atmel STK500/AVRISP/AVR Prog, Kanda Systems STK200+/300, Dontronics DT006, Vogel Electronic VTEC-ISP, Futurlec JRAVR dan MicroTronics ATCPU/Mega 2000 rogrammers/development boards. Untuk keperluan debugging sistem embedded yang menggunakan komunikasi serial, IDE mempunyai sebuah fasilitas internal berupa sebuah terminal. Selain library standar C, CodeVisionAVR juga mempunyai library tertentu untuk modul LCD alphanumeric, bus I2C dari Philips, sensor suhu LM75 dari National Semiconductor, real-Time Clock (PCF8563, PCF8583 dari Philips, DS1307 dan DS1307 dari Maxim/Dallas Semiconductor, protokol 1-Wire dari 
Maxim/Dalas Semiconductor, sensor suhu (DS1820, DS18S20 dan DS18B20 dari Maxim/Dallas Semiconductor), thermometer/Thermostat DS1621 dari Maxim/Dallas Semiconductor,EEPROM DS2430 dan DS2433 dari Maxim/DallasSemiconductor, SPI (Serial Pheriperal Interface), power management, delay, Konversi ke Kode Gray. CodeVisionAVR juga mempunyai fasilitas Automatic Program Generator bernama CodeWizardAVR yang dapat membantu menulis semua instruksi untuk membuat fungsi berikut:

1.Inisialisasi port Input/Output.

2.Inisialisasi interupsi eksternal.

3.Inisialisasi Timer/Counter.

4.Inisialisasi Watchdog Timer.

5.Inisialisasi UART atau USART dan komunikasi serial berbasis buffer yang digerakan oleh interupsi.

6.Inisiaisasi pembanding analog (Analog Comparator).

7. Inisialisasi ADC.

8.Inisialisasi antarmuka SPI.

9.Inisialisasi antarmuka 2-Wire

10. Inisialisasi Bus I2C, Sensor Suhu LM75, Thermometer/Thermostat DS1621 dan Real-Time Clock PCF8563, PCF8583, DS1302 dan DS1307.

11. Inisialisasi Bus 1-Wire dan Sensor Suhu DS1820 dan DS18S20.

Inisialisasi Modul LCD.

\section{Konfigurasi Pin LCD}

Untuk keperluan antarmuka suatu komponen elektronik dengan mikrokontroler, perlu diketahui fungsi dari setiap kaki pada LCD. Gambar 2 menunjukkan modul LCD karakter 2x16.

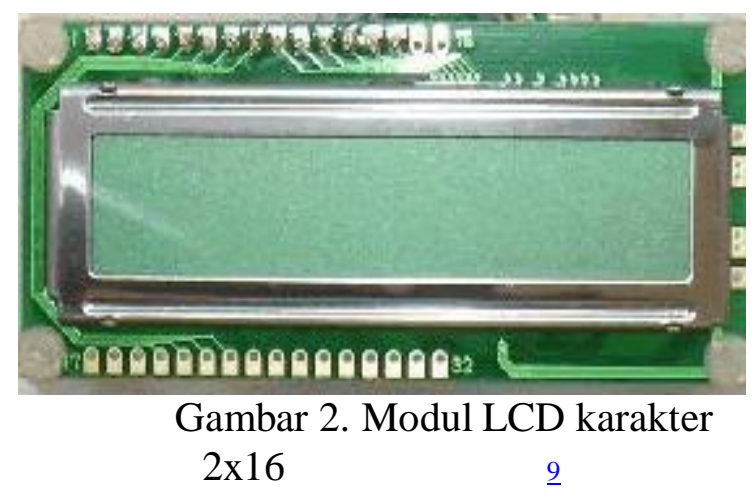

Dari gambar diatas dapat dijelasakan fungsi dari setiap kaki pada LCD, sebagai berikut:

1. Kaki 1 (GND)

Kaki ini dihubungkan dengan tegangan +5 Volt yang merupakan tegangan untuk sumber daya dari HD44780 (khusus untuk modul M1632 keluaran hitachi, kaki ini adalah VCC)

2. Kaki 2 (VCC)

Kaki ini dihubungkan dengan tegangan 0 volt (ground) dan modul LCD (khusus untuk modul M1632 keluaran hitachi, kaki ini adalah GND)

3. Kaki 3 (VEE/VLCD)

Tegangan pengatur kontras LCD, kaki ini terhubung pada V5. Kontras mencapai nilai maksimum pada saat kondisi kaki ini pada tegangan 0 volt.

4. Kaki 4 (RS)

Register Select, kaki pemilih register yang akan diakses. Untuk akses ke register data, logika dari kaki ini adalah 1 dan untuk akses ke register perintah, logika dari kaki ini adalah 0 .

5. Kaki $5(\mathrm{R} / \mathrm{W})$

Logika 1 pada kaki ini menunjukkan bahwa modul LCD sedang pada mode pembacaan dan logika 0 menunjukkan bahwa modul LCD sedang pada mode penulisan. Untuk aplikasi yang tidak memerlukan pembacaan data 
pada modul LCD, kaki ini dapat dihubungkan langsung ke ground.

\section{Kaki 6 (E) Enable}

Clock LCD, kaki ini mengaktifkan clock LCD. Logika 1 pada kaki ini diberikan pada saat penulisan atau pembacaan data.

7. Kaki 7-14 (D0-D7)

Data bus, kedelapan kaki modul LCD ini adalah bagian dimana aliran data sebanyak 4 bit atau 8 bit mengalir saat proses penulisan maupun pembacaan data.

8. Kaki 15 (Anoda)

Berfungsi untuk tegangan positif dari backlight modul LCD sekitar 4,5 volt (hanya terdapat untuk M1632 yang memiliki backlight).

9. Kaki 16 (Katoda)

Tegangan negatif backlight modul LCD sebesar 0 volt (hanya untuk M1632 yang memiliki backlight).

\section{METODOLOGI}

Penelitian ini telah dilakukan dengan menggunakan alat yang dibuat menggunakan motor sebagai pengaduk dan mikrokontroler sebagai pengontrol objek yang talah dilakukan untuk pengadudukan pupuk kompos

Adapun langkah-langkah yang harus dilakukan selama melakukan penelitian ilmiah adalah sebagai berikut:

1. Mengidentifikasi dan merumuskan masalah

2. Melakukan studi pendahuluan

3. Merumuskan hipotesis

4. Mengidentifikasi variabel dan definisi operasional variabel

5. Menentukan rancangan dan desain penelitian

6. menentukan dan mengembangkan instrumen penelitian

7. menentukan subjek penelitian

8. melaksanakan penelitian

9. melakukan analisis data
10. merumuskan hasil penelitian dan pembahasan

Parameter penelitian yang dilakuakan :

1. Sistim Minimum dengan nilai tegangan 5 VDC sebagai input IC ATMega 8535. dari rangkaian.

2. Pengaturan waktu yang downloadkan ke IC ATMega 8535 sehingga didapatkan peguraian dari bakteri maksimal untuk mendapatkan pupuk kompos yang diinginkan.

Perancangan secara umum dari sistem pembuatan alat penghadukan pupuk kompos ini dapat dilihat pada blok diagram di berikut ini:

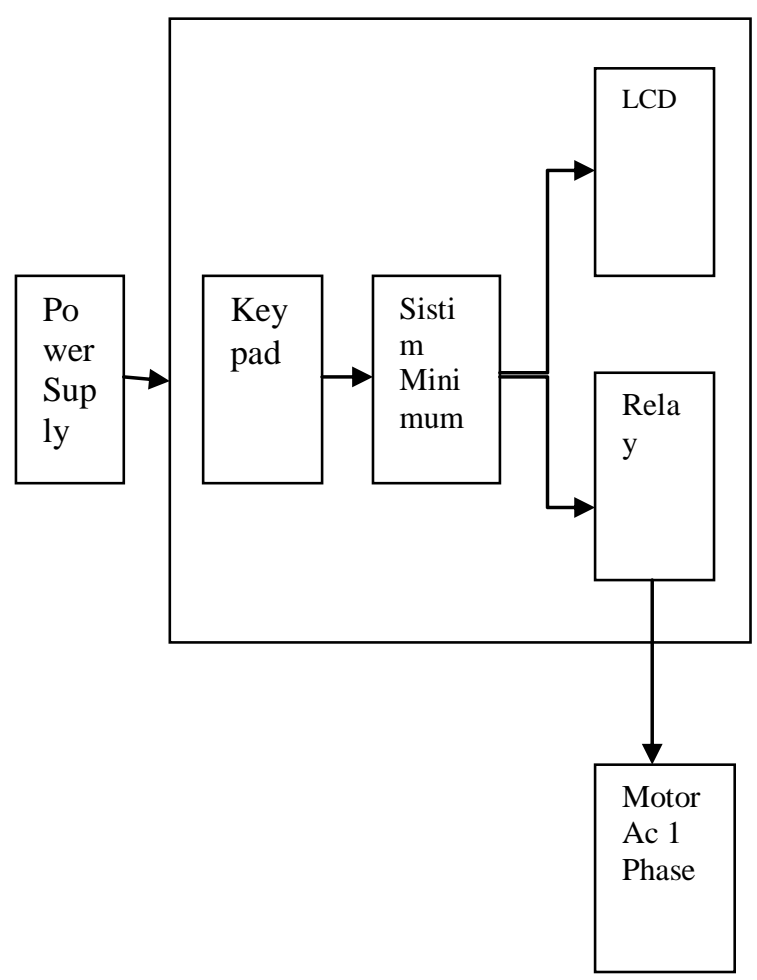

Gambar 3. Blok Diagram Sistem Pembuatan Alat Pengadukan Pupuk Kompos.

Pengontrol utama dari sistem Pembuatan Alat Pengadukan Pupuk kompos ini adalah mikrokontroller. Mikro akan memproses data yang dikirimkan dari objek, yaitu motor yang berfungsi untuk memutarkan wadah pengadukan. Dan data dari proses pengadukan akan ditampilkan ke LCD. 
Pengontrol yang digunakan adalah mikrokontroller AVR Atmega8535. Mikrokontroler adalah pengendali mikro yang berbentuk chip (atau IC) yang dapat diprogram menggunakan komputer. Di dalam chip tersebut terdapat ruang untuk menyimpan program dan ruang menyimpan data (EEPROM). Mikrokontroler adalah otak elektronik yang dapat mengendalikan perangkat-perangkat elektronik lain nya. Misalnya mengendalikan relay, menampilkan gambar di LCD, dsb.

Perancangan Rangkaian Sistim Minimum

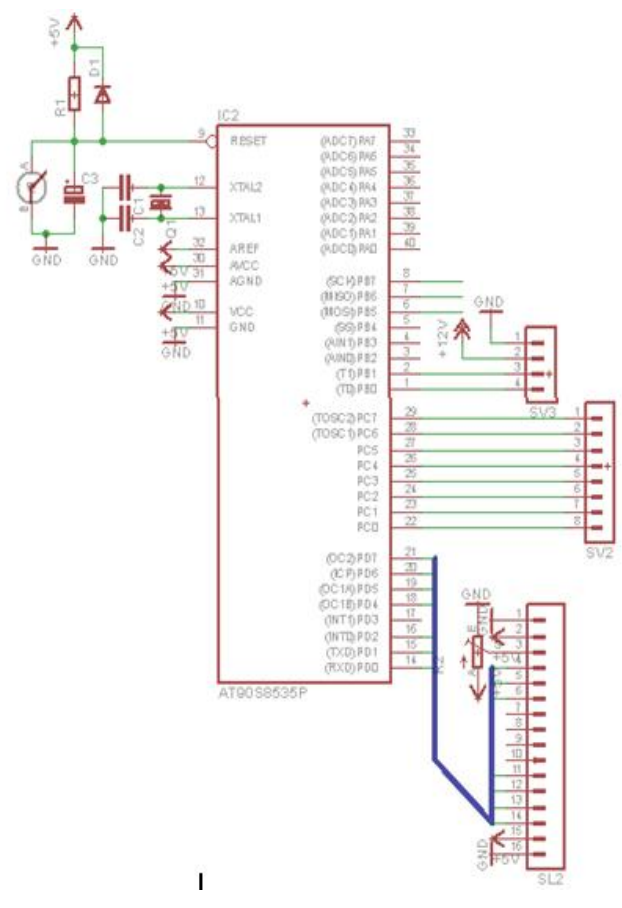

Gambar 4. Schematic sistem minimum

Pada perancangan dan pembuatan alat ini, sistem minimum yang digunakan menggunakan mikrokontroller ATMega8535. Rangkaian sistem minimum ini berfungsi sebagai pusat kendali dari seluruh sistem yang ada. Rangkaian sistem minimum merupakan rangkaian yang berguna untuk menunjang proses kerja mikrokontroller. Port B digunakan ke rangkaian relay dan Port $\mathrm{C}$ digunakan sebagai switch, Port D digunakan sebagai keluaran data yang akan ditampilkan pada LCD
Langkah pertama dalam merancang software adalah membuat algoritma program. Dari flowchart akan terlihat dengan jelas arah jalannya suatu program. Flowchart dari sistem ini adalah:

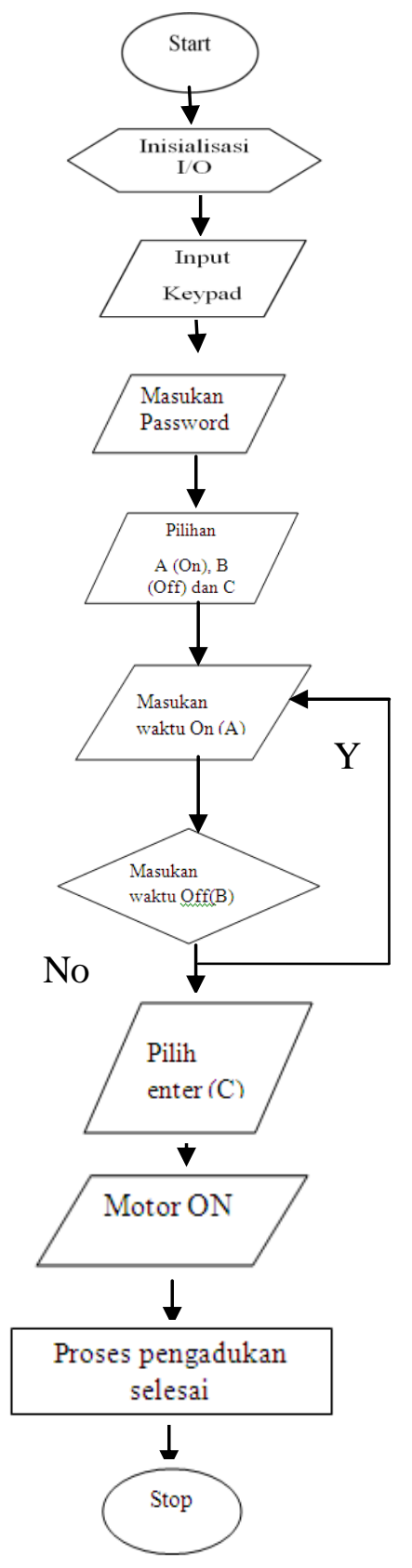

Gambar 5. Flowchart Sistem Pembuatan Alat Pengadukan Pupuk Kompos.

Berdasarkan flowchart diatas, secara umum pada pembuatan alat pengadukan kompos, keypad sebagai input yang akan mengatur timer yang diberikan, pengaturan timer dilakukan pada saat On dan Off kemudian masuk ke kontroller, dan langsung di proses oleh mikro. 


\section{Motor AC 1 Phase}

Diagram Motor Ac 1 Phase

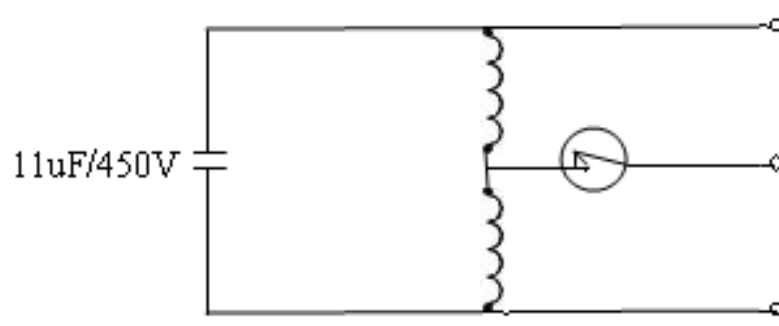

\section{Rangkaian Keypad 4x4}

Dalam perancangan alat ini dibutuhkan sebuah keypad sebagai inputan BlukeCCW)

mikrokontroler yang berfungsi untuk menjalankan suatu aplikasi yang sudah jadi,

Bladengan adanya keypad dapat menginputkan suatu besaran nilai yang dinginkan dan selain itu dapat memerintahkan suatu Redúlikăbisi agar dapat di proses.

Gambar 6.. Diagram motor AC 1 phase

Pada diagram motor AC satu phase ini menjelaskan ada dua arah putaran motor yaitu clockwise $(\mathrm{CW})$ yang beputar searah jarum jam dan counter clockwise (CCW) yang berputar berlawanan arah jarum jam. Kabel yang digunakan ada tiga jenis warna yaitu warna biru dan merah terhubung ke kapasitor sedangkan warna hitam terhubung ke trafo. Rangkaian LCD

Tipe LCD yang digunakan adalah LCD M1632, LCD ini mempunyai tampilan sebanyak 16 kolom 2 baris. Pin 1 dan 2 adalah untuk sumber tegangan LCD, dan pin 3 LCD dihubungkan dengan potensiometer $10 \mathrm{k} \Omega$ yang dirangkai sebagai pembagi tegangan sehingga perubahan tegangan tersebut dapat digunakan untuk mengatur kontras tampilan pada LCD. Sementara koneksi ke LCD pin yang dipakai adalah pin 7 , pin 8 , pin 9 ,pin 10,pin 11,pin 12 yang mana:

1. Pin 7 dihubungkan ke RS

2. Pin 8 dihubungkan ke $\mathrm{E}$

3. Pin 9 dihubungkan ke D4

4. Pin 10 dihubungkan ke D

5. Pin 11 dihubungkan ke D6

6. Pin 12 dihubungkan ke D7

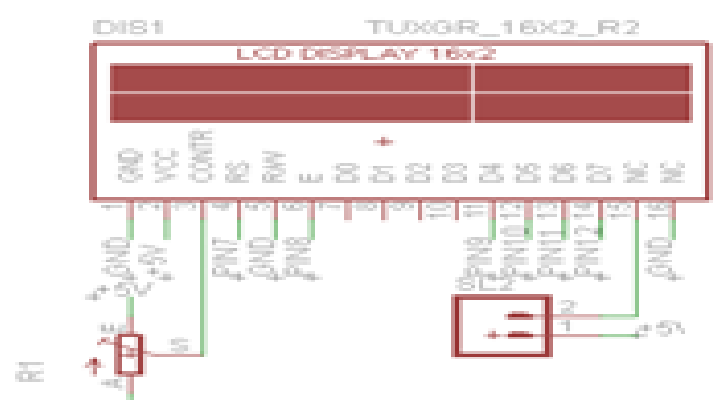

Gambar 7 Rangkaian LCD

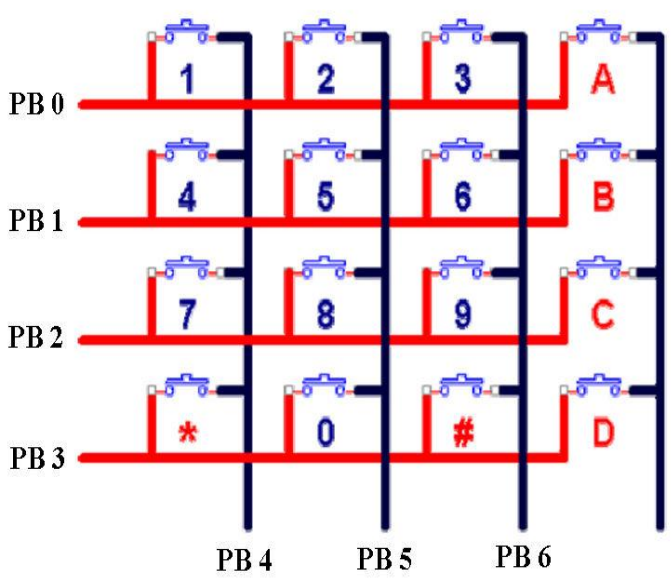

Gambar 8 Rangkaian Keypad

\section{HASIL}

Pengujian dilakukan pada tiap-tiap blok. Pengujian sistem dan analisa data merupakan suatu langkah untuk mengetahui apakah sistem yang dibuat sesuai dengan yang direncanakan dan sesuai dengan teori atau tidak, jika tidak sesuai dengan teori, maka perbedaan tersebut dapat diketahui penyebabnya dari analisa data. Dalam melakukan pengujian dibutuhkan alat uji sebagai adalah multimeter.

Besar tegangan sumber untuk sistem minimum ini adalah $+5 \mathrm{~V}$ DC dan kebutuhan tegangan tersebut telah terpenuhi

Untuk pengujian sistem minimum jalur yang perlu di persiapkan adalah alat ukur seperti multimeter. Prinsip pengujian pada sistem minimum ini adalah untuk mengecek apakah semua jalur yang ada terhubung dengan semestinya.Untuk mengetahui apakah rangkaian sistem minimum yang digunakan bekerja dengan baik kita hanya perlu melihat indikator led 
nyala. Berikut ini hasil pengujian sistim minimum.

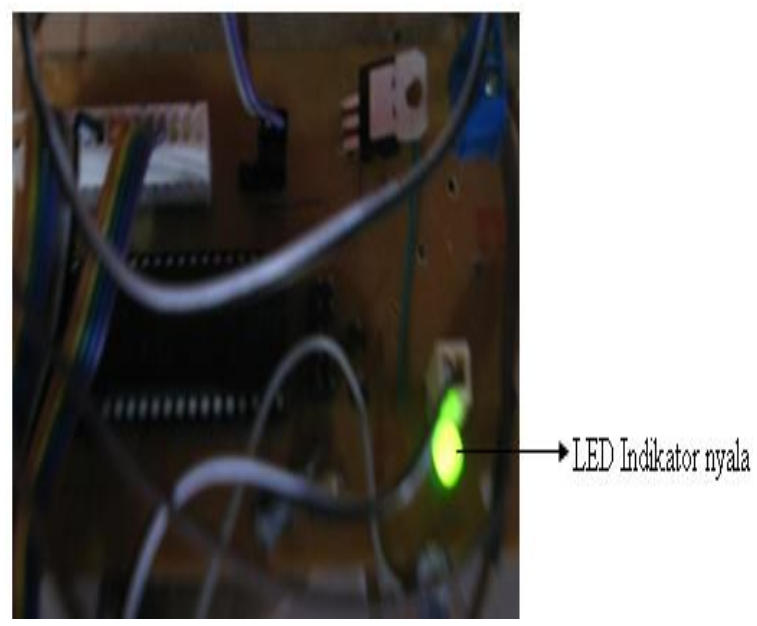

Gambar 9. Pengujian sistim minimum

Dari pengujian dapat dianalisa bahwa, rangkaian system minimum dapat dikatakan berfungsi dengan baik apabila output pada masing-masing port dapat terbaca oleh multimeter. Apabila tidak maka perlu di lakukan lagi pengecekan pada masingmasing.Jika tidak ada kesalahan pada sistem minimum namun masih tidak bekerja, kemungkinan ada kerusakan pada pada IC ATMega 8535.

Besar tegangan sumber untuk rangkaian ini adalah $+5 \mathrm{~V}$ DC dan kebutuhan tegangan tersebut telah terpenuhi. Rangkaian ini merupakan pusat kontrol dari keseluruhan sistem. Pemogramannya dilakukan dengan menggunakan bahasa $\mathrm{C}$ dan selanjutnya akan didownloadkan pada memori internal yang telah tesedia.

Konstruksi matrix keypad $4 \times 4$ diatas cukup sederhana, yaitu terdiri dari 4 baris dan 4 kolom dengan keypad berupas saklar push buton yang diletakan disetiap persilangan kolom dan barisnya. Rangkaian matrix keypad diatas terdiri dari 16 saklar push buton dengan konfigurasi 4 baris dan 4 kolom. 8 line yang terdiri dari 4 baris dan 4 kolom tersebut dihubungkan dengan port mikrokontroler 8 bit. Sisi baris dari matrix keypad ditandai dengan nama Row0, Row1, Row2 dan Row3 kemudian sisi kolom ditandai dengan nama Col0, Col1, Col2 dan Col3. Sisi input atau output dari matrix keypad $4 \times 4$ ini tidak mengikat, dapat dikonfigurasikan kolom sebagi input dan baris sebagai output.

Proses scaning untuk membaca penekanan tombol pada matrix keypad $4 \times 4$ untuk mikrokontroler diatas dilakukan secara bertahap kolom demi kolom dari kolom pertama sampai kolom ke 4 dan baris pertama hingga baris ke 4 . Program untuk scaning matrix keypad $4 \times 4$ dapat bermacam-macam, tapi pada intinya sama. Maka proses scaning matrix keypad $4 \times 4$ diatas dapat dituliskan sebagai berikut.

Mengirimkan logika Low untuk kolom 0 (Col0) dan logika High untuk kolom yang lain kemudian membaca data baris, misal tombol SW1 ditekan maka data baris pertama (Row0) akan Low sehingga data baris yang dibaca adalah 01110111 .

Tabel 1. Nilai logika yang ada pad switch

\begin{tabular}{llll}
\hline Switch & Logika & Switch & Logika \\
\hline SW1 & 0111 & SW9 & 0111 \\
(C0,R0) & 0111 & (C0,R2) & 1101 \\
\hline SW2 & 1011 & SW10 & 1011 \\
(C1,R0) & 0111 & (C1,R2) & 1101 \\
\hline SW3 & 1101 & SW1 & 1101 \\
(C2,R0) & 0111 & 1(C2,R2) & 1101 \\
\hline SW4 & 1110 & SW1 & 1110 \\
(C3,R0) & 0111 & 2(C3,R2) & 1101 \\
\hline SW5 & 0111 & SW1 & 0111 \\
(C0,R1) & 1011 & 3(C0,R3) & 1110 \\
\hline SW6 & 1011 & SW1 & 1011 \\
(C1,R1) & 1011 & 4(C1,R3) & 1110 \\
\hline SW7 & 1101 & SW1 & 1101 \\
(C2,R1) & 1011 & 5(C2,R3) & 1110 \\
\hline SW8 & 1110 & SW1 & 1110 \\
(C3,R1) & 1011 & 6(C3,R3) & 1110 \\
\hline
\end{tabular}

Keypad adalah sebuah program untuk membaca penekanan tombol pada keypad prosedur keypad akan memberikan suatu nilai bila ada penekanan tombol. Berdasarkan tabel diatas keypad digunakan untuk password dan pengaturan waktu (detik). Tombol password yang diberikan pada keypad ini adalah "13C\#", sedangkan untuk pengaturan waktunya ada dua pilihan yaitu waktu on (tombol A) sedangkan untuk 
time off (tombol B) dan untuk enternya adalah tombol $\mathrm{C}$.

Penekanan tombol berarti "C" dan " $\mathrm{R}$ " berlogika 0 , tegangan yang terukur adalah $5 \mathrm{~V}$, karena menggunakan saklar Push Button di setiap tombolnya, Kolom dan baris terhubung langsung ke Vcc dari mikrokontroler. Begitu seterusnya untuk penekanan tombol keypad yang lain, tegangan yang terukur tetap $5 \mathrm{~V}$.

Tabel 2. Hasil pengujian pengadukan pupuk.

\begin{tabular}{|c|c|c|c|c|}
\hline No. & $\begin{array}{l}\text { Waktu } \\
\text { On } \\
(\mathrm{CW})\end{array}$ & $\begin{array}{l}\text { Wa } \\
\text { ktu } \\
\text { Off } \\
\end{array}$ & $\begin{array}{l}\text { Waktu } \\
\text { On } \\
(\mathrm{CCW})\end{array}$ & $\begin{array}{l}\text { Hasil } \\
\text { Pengadukan }\end{array}$ \\
\hline 1. & 2 Detik & $\begin{array}{l}30 \\
\text { Deti } \\
\mathrm{k}\end{array}$ & 2 Detik & \\
\hline 2. & 4 Detik & $\begin{array}{l}30 \\
\text { Deti } \\
\mathrm{k}\end{array}$ & 4 Detik & \\
\hline 3. & 6 Detik & $\begin{array}{l}30 \\
\text { Deti } \\
\mathrm{k}\end{array}$ & 6 Detik & \\
\hline 4. & 8 Detik & $\begin{array}{l}30 \\
\text { Deti } \\
\mathrm{k}\end{array}$ & 8 Detik & \\
\hline 5. & $\begin{array}{l}10 \\
\text { Detik }\end{array}$ & $\begin{array}{l}30 \\
\text { Deti } \\
\mathrm{k}\end{array}$ & 10 Detik & \\
\hline
\end{tabular}

\section{PEMBAHASAN}

Berdasarkan hasil pengujian diatas yaitu hasil perbandingan hasil pengadukan berbeda-beda. Semakin lama waktu yang diberikan maka pengadukan semakin merata.

Proses pertama pada pengadukan pupuk kompos ini dengan memasukkan bahan-bahan yaitu sekam padi, tanah / lembah karet dan pupuk kandang, setelah bahan-bahan dimasukkan maka proses selanjutnya adalah pengadukan. Proses pengadukan dilakukan dengan cara berputarnya motor yang searah jarum jam (CW) dan berlawanan arah jarum jam $(\mathrm{CCW})$. Cara kerja alat pengadukan ini yaitu pengadukan berputar (selama waktu yang di atur), Setelah itu alat pengadukan berhenti (selama waktu yang diatur). Pada alat pengadukan berhenti maka cairan bakteri dimasukkan untuk penguraian atau pembusukkan pupuk kompos yang telah diaduk dan alat pengaduk berputar kembali, setelah itu alat berhenti dan proses pengadukan selesai.

\section{Pengujian Pupuk Kompos}

Berikut ini hasil pengujian pupuk kompos:

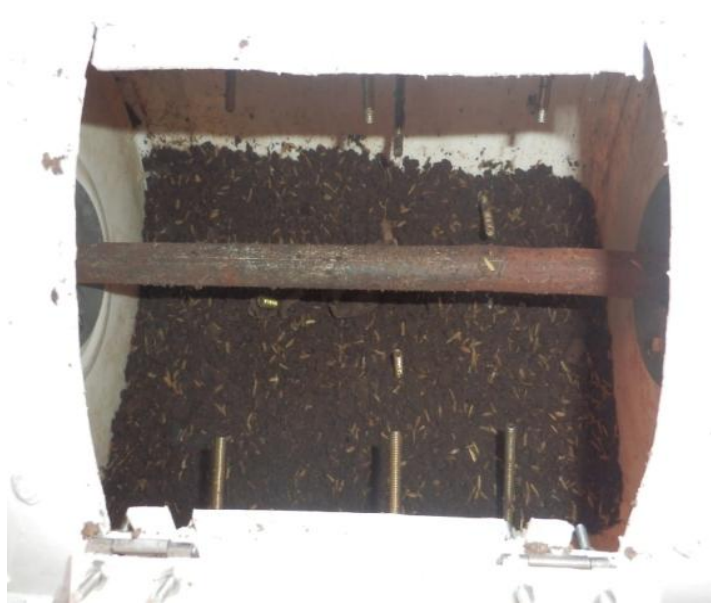

Gambar 10. Hasil pengujian proses

pengadukan pupuk kompos 
Proses pertama pada pengadukan pupuk kompos ini dengan memasukkan bahan-bahan yaitu sekam padi, tanah dan pupuk kandang, setelah bahan-bahan dimasukkan maka proses selanjutnya adalah pengadukan. Proses pengadukan dilakukan dengan cara berputarnya motor yang searah jarum jam selama 20 detik dan kemudian berhenti selama 30 detik. Pada saat proses pengadukan berhenti maka cairan bakteri dimasukan. Dan proses pengadukan bekerja kembali dengan putaran berlawanan dengan arah jarum jam selama 20 detik.

\section{Program}

\#include <mega8535.h>

// Alphanumeric LCD Module functions

\#include <alcd.h>

\#include <stdio.h>

\#include <delay.h>

\#define swki PINC.4

\#define swte PINC.3

\#define swka PINC.2

unsigned char line1[16], line2[16];

int count $=1$;

unsigned int hidup,mati;

eeprom unsigned int seton,setoff;

unsigned int aturon, aturoff;

void menu();

void $\mathrm{cw}()$;

void $\operatorname{ccw}()$;

void off();

void main(void)

\{

PORTB $=0 \times 00$;

$\mathrm{DDRB}=0 \mathrm{x} 03$;

PORTC $=0 \times 1 \mathrm{~F}$;

$\mathrm{DDRC}=0 \mathrm{x} 00$;

lcd_init(16);

\#asm("sei")

if( seton==-1) $\{$ seton $=0 ;\}$

if $($ setoff $<20000)$ \{ setoff $=20000 ;\}$

while(swki\&\&swte\&\&swka) \{

lcd_gotoxy $(0,0)$;

lcd_putsf("AFRIZAL CHANDRA");

lcd_gotoxy $(0,1)$;

lcd_putsf(" ");

lcd_gotoxy $(0,1)$; delay_ms(100);

lcd_putsf("press ");

lcd_gotoxy $(0,1)$;

delay_ms(100);

lcd_putsf("press any ");

lcd_gotoxy $(0,1)$;

delay_ms(100);

lcd_putsf("press any key. ");

lcd_gotoxy $(0,1)$;

delay_ms(100);

lcd_putsf("press any key..");

lcd_gotoxy $(0,1)$;

delay_ms(100);

lcd_putsf("press any key...");

lcd_gotoxy $(0,1)$;

delay_ms(100);

\}

while (1)

\{

//output oke

delay_ms(1000);

PORTB. $1=0$;

delay_ms $(1000)$;

PORTB. $0=1$;

delay_ms $(1000)$;

PORTB. $0=0$;

delay_ms(1000);

lcd_clear();

lcd_gotoxy $(0,0)$;

lcd_putsf("tes switch");

delay_ms $(10) ; \quad *$ /

$/{ }^{*}$ while(swki==0) $\{$ lcd_clear( $) ; 1 c d$ gotoxy $(0$

,0);lcd_putsf("kiri");delay_ms(100); \}

while $($ swte $==0)\{$ lcd_clear ()$; 1$ lcd_gotoxy $(0,0$

);lcd_putsf("tengah");delay_ms(100);

while $($ swka $==0)\{\operatorname{lcd}$ _clear ()$; \operatorname{lcd}$ _gotoxy $(0$,

0);lcd_putsf("kanan");delay_ms(100);

*/

//PORTB.0=1;

//delay_ms(1000);

//PORTB. $0=0$;

//delay_ms(10000);

menu();

\}

\}

void menu( $)\{$

if $(\mathrm{swki}==0)\{$ while $($ swki $==0)\{\}$

delay_ms(15); 


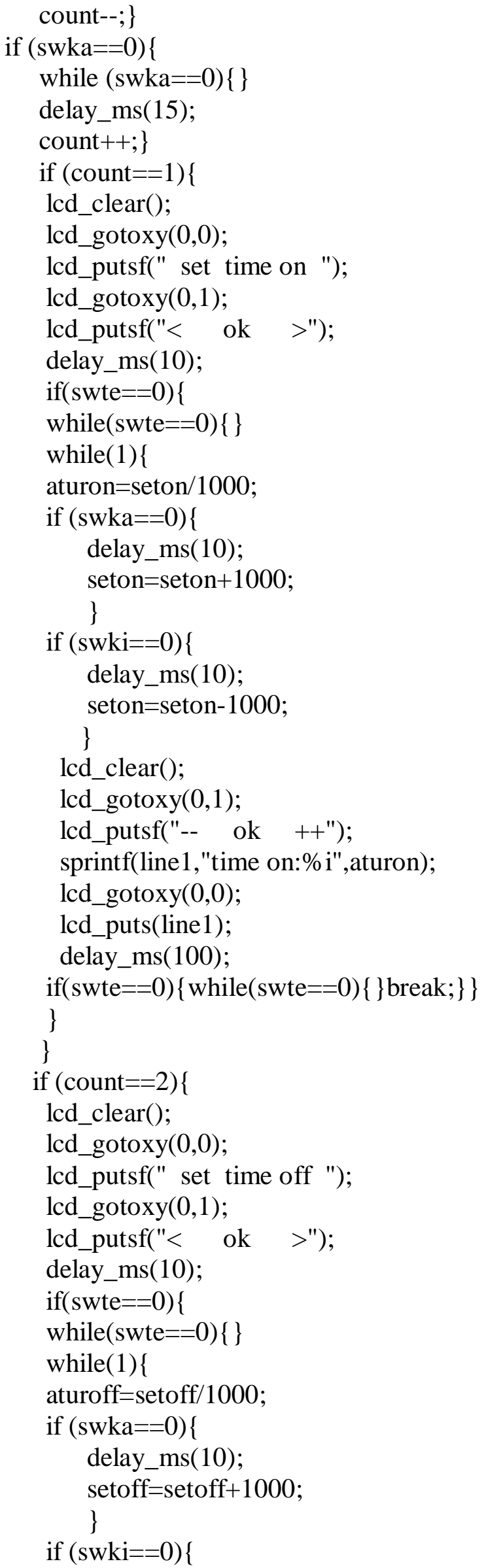

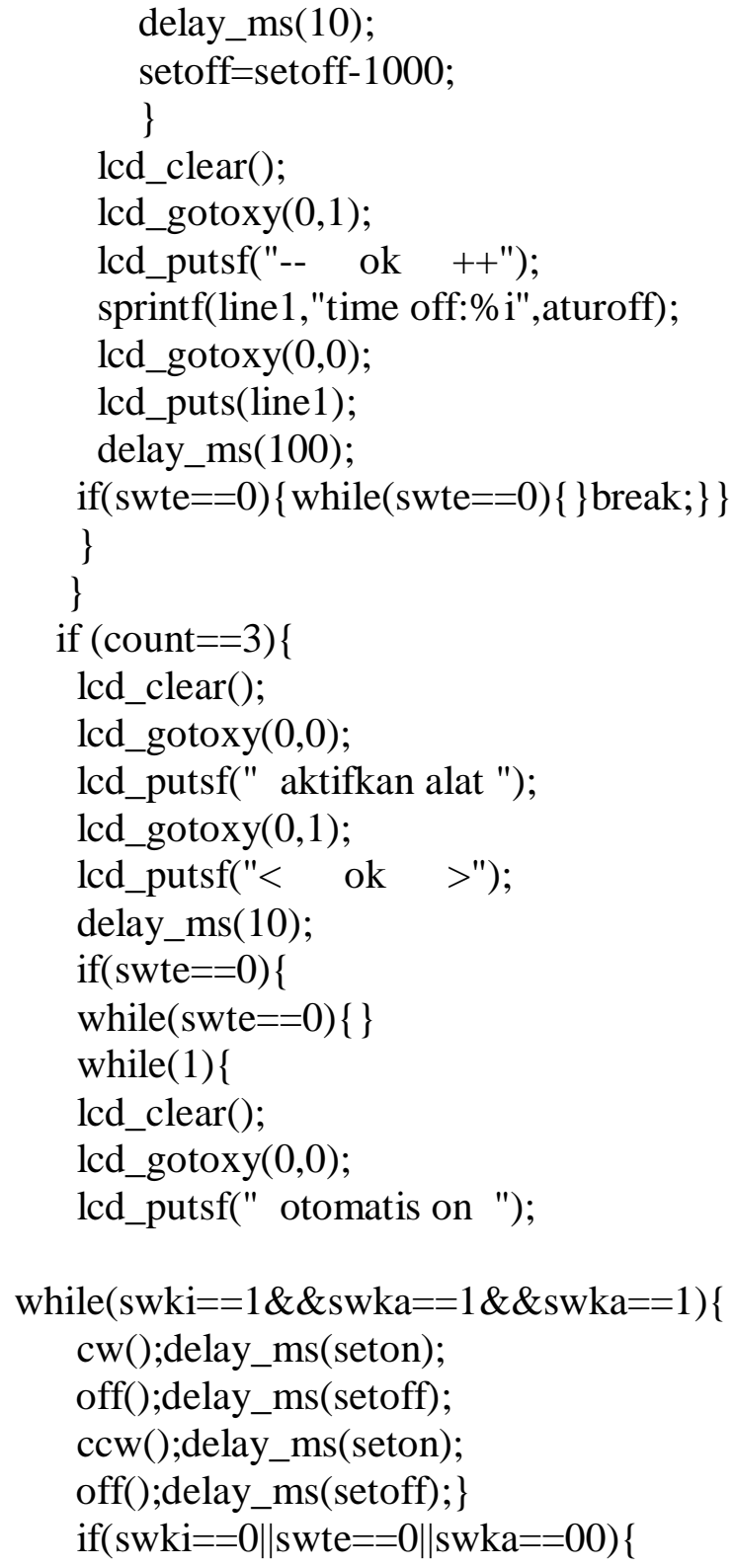

\section{SIMPULAN}

Berdasarkan hasil penelitian, dapat diperoleh beberapa kesimpulan yaitu:

1) Pada pembuatan alat pengadukan pupuk kompos berbasiskan mikrokontroller ini menggunakan rangkaian sistim minimum, relay, LCD dan keypad.

2) Kapasitor berfungsi sebagai komponen elektronika yang dapat menyimpan muatan listrik.

3) Relay berfungsi untuk memutuskan atau menghubungkan suatu rangkaian elektronik yang satu dengan rangkaian elektronik yang lain. 
4) Pada tahapan pengadukan ini diperlukan password untuk menjalankan kerja dari motor.

5) Pada sistem pengadukan ini, pengaturan untuk waktunya dapat kita atur sesuai yang dibutuhkan yang diatur pada program

\section{DAFTAR PUSTAKA}

Assidu. JJ. 1987. Processing tropical Crops. Heryanto.ST, M.Ary. Ir. Wisnu Adi. 2008. Yogyakarta P. 'Pemograman Bahasa C untuk mikrokontroler AVR 8535'

Kurniawan.ST, Freddy. 2005. 'Sistem Digital konsep dan Aplikasi'. Yogyakarta: Gava Media.

Winoto,A.(2008). Mikrokontroler AVR dan pemogramannya dengan bahasa $\mathrm{C}$. Jogjakarta: Gava media 